\title{
Author Correction: Antibiotic susceptibility signatures identify potential antimicrobial targets in the Acinetobacter baumannii cell envelope
}

\author{
Edward Geisinger (1), Nadav J. Mortman, Yunfei Dai, Murat Cokol (D), Sapna Syal, Andrew Farinha, \\ Delaney G. Fisher (D), Amy Y. Tang, David W. Lazinski, Stephen Wood, Jon Anthony, Tim van Opijnen (D) \&
} Ralph R. Isberg (D)

Correction to: Nature Communications https://doi.org/10.1038/s41467-020-18301-2, published online 9 September 2020

The original version of this Article contained the following errors:

In the Results, subsection 'Phenotypic signature analysis identifies shape determinants', a protein with homology to PBP5 and PBP6 D, D-carboxypeptidases was incorrectly referred to as 'ACX60_RS04555'; the protein name has been corrected to 'ACX60_ RS05395'.

Another mislabelling error was present in Figure 5f; the correct version states 'ACX60_ RS05395' in place of 'ACX60_RS05685'.

In addition, the colour fill within dotted error lines (indicating s.d.) was missing from Figures $3 \mathrm{~b}, 3 \mathrm{~g}, 4 \mathrm{c}, 4 \mathrm{~d}, 5 \mathrm{~d}$ and $5 \mathrm{e}$.

These errors have been corrected in both the PDF and HTML versions of the Article.

Published online: 24 November 2020

\begin{abstract}
(c) (i) Open Access This article is licensed under a Creative Commons Attribution 4.0 International License, which permits use, sharing, adaptation, distribution and reproduction in any medium or format, as long as you give appropriate credit to the original author(s) and the source, provide a link to the Creative Commons license, and indicate if changes were made. The images or other third party material in this article are included in the article's Creative Commons license, unless indicated otherwise in a credit line to the material. If material is not included in the article's Creative Commons license and your intended use is not permitted by statutory regulation or exceeds the permitted use, you will need to obtain permission directly from the copyright holder. To view a copy of this license, visit http://creativecommons.org/licenses/by/4.0/.
\end{abstract}

(c) The Author(s) 2020 